\title{
PERANAN CROSS EQUATORIAL NORTHERLY SURGE TERHADAP DINAMIKA ATMOSFER DI WILAYAH INDONESIA BAGIAN BARAT
}

\author{
The Role of Cross Equatorial Northerly Surge to Atmospheric Dynamics in \\ Western Indonesia Region
}

\author{
Tyas Tri Pujiastuti ${ }^{1)^{*}}$, Nurjaman ${ }^{1)}$ \\ 1) Pusat Meteorologi Publik, Badan Meteorologi Klimatologi dan Geofisika. Jl. Angkasa I No.2 Kemayoran \\ Jakarta Pusat 10720 \\ *E-mail: tyas.pujiastuti@bmkg.go.id
}

\begin{abstract}
Intisari
Pada saat monsun dingin Asia berlangsung pada Oktober hingga Maret, sebagian wilayah Indonesia mengalami peningkatan curah hujan yang signifikan dibandingkan saat periode April hingga September. Selain dari pengaruh monsun, cuaca di wilayah Indonesia juga dipengaruhi oleh sirkulasi skala global dan regional yang terjadi secara simultan. Hal ini dapat memengaruhi dinamika atmosfer di sebagian wilayah Indonesia. Pada penelitian ini, dikaji aktivitas cross equatorial northerly surge yang terjadi pada skala regional serta dampaknya terhadap dinamika atmosfer di wilayah Indonesia bagian barat khususnya Laut China Selatan bagian selatan hingga Laut Jawa. Hasil penelitian menunjukkan bahwa cross equatorial northerly surge pada tahun 2013 terjadi paling kuat pada saat bersamaan dengan cold surge, dan memengaruhi pola divergensi, transpor kelembapan, dan omega, terutama di wilayah utama pada penelitian ini yaitu perairan Laut China Selatan hingga Laut Jawa, yang berpotensi mendukung terjadinya cuaca buruk di wilayah Bangka Belitung dan Jawa bagian barat.
\end{abstract}

Kata Kunci: Cross Equatorial Northerly Surge, Dinamika Atmosfer.

\begin{abstract}
During the Asia winter monsoon from October to March, parts of the Indonesian region experienced significant rainfall increases compared to the period from April to September. Apart from monsoon influence, the weather in the Indonesian region was also influenced by global and regional scale circulations, which occurred simultaneously. This can affect atmospheric dynamics in parts of the Indonesian region. In this study, the activities of cross-equatorial northerly surge that occurred on a regional scale and its impact on atmospheric dynamics conditions in western Indonesia, especially the southern South China Sea to the Java Sea, are examined. The results showed that the crossequatorial northerly surge in 2013 occurred most strongly at the same time as cold surge, and influenced divergence, moisture transport, and omega patterns, particularly in the main research areas including South China Sea to the Java Sea, which have the potential to excite severe weather in Bangka Belitung and Western part of Java.
\end{abstract}

Keywords: Cross Equatorial Northerly Surge, Atmospheric Dynamics.

\section{PENDAHULUAN}

Letak wilayah Indonesia di antara benua Asia dan Australia menjadikan cuaca dan iklim di wilayah Indonesia sangat dipengaruhi oleh kondisi cuaca dan iklim di kedua benua tersebut. Dengan adanya perbedaan radiasi matahari yang diterima wilayah lintang tinggi dan equator menyebabkan perbedaan tekanan, sehingga terjadilah aliran udara dari wilayah dengan tekanan tinggi ke tekanan rendah. Hal ini menjadi salah satu faktor pengendali iklim di wilayah Indonesia, karena pada saat itu pola angin di wilayah Indonesia berganti secara periodik dan menyebabkan perubahan musim di sebagian wilayah Indonesia.
Pada Oktober hingga Maret, secara umum sebagian wilayah Indonesia khususnya bagian barat akan mengalami peningkatan konvektifitas terkait dengan pola angin di wilayah Indonesia yang berhembus dari arah utara yang cenderung membawa uap air setelah melewati wilayah perairan hangat yang luas (Moron et al., 2010; Chang et al., 2016). Pada periode ini, wilayah Belahan Bumi Utara sedang mengalami musim dingin. Pada saat itu aliran udara bergerak dari Belahan Bumi Utara menuju Belahan Bumi Selatan dan dapat memengaruhi kondisi cuaca di sebagian wilayah Indonesia.

Adapun aliran udara dari Belahan Bumi Utara melintasi equator ini disebut sebagai aliran 
lintas ekuator (cross equatorial flow). Berdasarkan penelitian sebelumnya, adanya cross equatorial flow ini ditandai dengan arah angin dominan dari utara di wilayah equator, sehingga seringkali disebut juga sebagai Cross Equatorial Northerly Surge (CENS) (Hattori et al., 2011). Dengan adanya gaya coriolis, di wilayah Belahan Bumi Selatan terutama di wilayah Laut Jawa, adanya cross equatorial flow ini terlihat sebagai arah angin dominan dari barat laut hingga barat (Swarinoto, 1996).

CENS berkaitan erat dengan peningkatan rata - rata curah hujan di sebagian wilayah Indonesia (Hattori et al., 2011; Mori et al., 2016; Mori et al., 2018). Hal ini menunjukkan adanya pengaruh CENS terhadap dinamika atmosfer di sebagian wilayah Indonesia. Pada penelitian ini, dilakukan analisis terhadap beberapa parameter dinamika atmosfer meliputi angin zonal dan meridional, temperatur lapisan $925 \mathrm{mb}$, divergensi lapisan $925 \mathrm{mb}$, transpor kelembapan, serta vertical velocity yang merefleksikan potensi pergerakan vertikal massa udara (Zhang et al., 2019).

Analisis dilakukan khususnya di sebagian wilayah penjalaran CENS meliputi Laut Cina Selatan bagian selatan hingga Laut Jawa bagian barat. Selanjutnya, dari hasil penelitian ini dapat diketahui peranan CENS terhadap dinamika atmosfer yang berkaitan dengan peningkatan curah hujan di sebagian wilayah Indonesia. Adapun waktu penelitian dibatasi pada Januari hingga Maret 2013, merujuk pada penelitian oleh Yulihastin (2015) terdapat kejadian CENS signifikan di wilayah Indonesia.

\section{METODE}

\subsection{Data Penelitian} meliputi:

Data yang digunakan dalam penelitian ini

a. Data DASCAT / gridded daily-averaged wind and wind stress fields pada wilayah $5^{\circ} \mathrm{LS}-0^{\circ}$ dan $105^{\circ} \mathrm{BT}-115^{\circ} \mathrm{BT}$ bulan Januari - Maret 2013. Data ini mempunyai resolusi $0,25^{\circ} \mathrm{x}$ $0,25^{\circ}$, bersumber dari ftp://ftp.ifremer.fr/ifremer/cersat/products/gridd ed/MWF/L3/ASCAT/Daily.

b. Data interpolated OLR / Outgoing Longwave Radiation bulan Januari - Maret 2013, dengan resolusi $2,5^{\circ} \times 2,5^{\circ}$. data ini didapat dari http://www.esrl.noaa.gov/psd/data/gridded.

c. Data Reanalisis ERA Interim pada periode Januari - Maret 2013 dengan resolusi $0,125^{\circ} \mathrm{x}$ $0,125^{\circ}$ meliputi:

1) Angin zonal dan meridional lapisan $925 \mathrm{mb}$

2) Temperatur lapisan $925 \mathrm{mb}$

3) Divergensi lapisan $925 \mathrm{mb}$

4) Kelembapan spesifik lapisan $1000 \mathrm{mb}$ hingga $850 \mathrm{mb}$
5) Vertical velocity / omega lapisan $1000 \mathrm{mb}$ hingga $600 \mathrm{mb}$.

\subsection{Metode Penelitian}

Analisis dinamika atmosfer di wilayah penelitian meliputi beberapa parameter yang sangat memengaruhi pada proses pembentukan cuaca di suatu wilayah, diantaranya streamline, temperatur, divergensi, vertical velocity, serta transpor kelembapan. Masing-masing parameter tersebut dipilih pada lapisan 925 mb karena lapisan tersebut paling representatif untuk mengamati gejala atmosfer tanpa adanya gangguan pada lapisan bawah maupun lapisan atas atmosfer (Aldrian, 2007). Sementara untuk mengetahui penjalaran massa udara digunakan analisis transpor kelembapan berdasarkan parameter kelembapan spesifik dan angin pada lapisan 1000 hingga $850 \mathrm{mb}$.

Penggunaan time lag dimana analisis dilakukan pada masing - masing waktu sebelum kejadian, saat kejadian, dan setelah kejadian diterapkan pada setiap analisis untuk dapat menggambarkan secara jelas peranan CENS terhadap dinamika atmosfer di wilayah penelitian.

Merujuk pada penelitian yang dilakukan oleh Hattori (2011), kejadian CENS dapat diklasifikasi menjadi empat, yakni kejadian CENS bersama - sama dengan cold surge dan MJO, CENS bersama - sama dengan cold surge, CENS bersama - sama dengan MJO, dan CENS tanpa disertai cold surge maupun MJO. Adapun identifikasi kejadian CENS didasarkan pada indeks CENS dengan menggunakan data DASCAT, yakni kecepatan angin meridional di $5^{0}$ LS $-0^{0}$ dan $105^{\circ}$ BT $-115^{\circ}$ BT yang mencapai atau melebihi $5 \mathrm{~m} / \mathrm{s}$, indeks ini disajikan dalam bentuk diagram hovmoller waktu terhadap lintang.

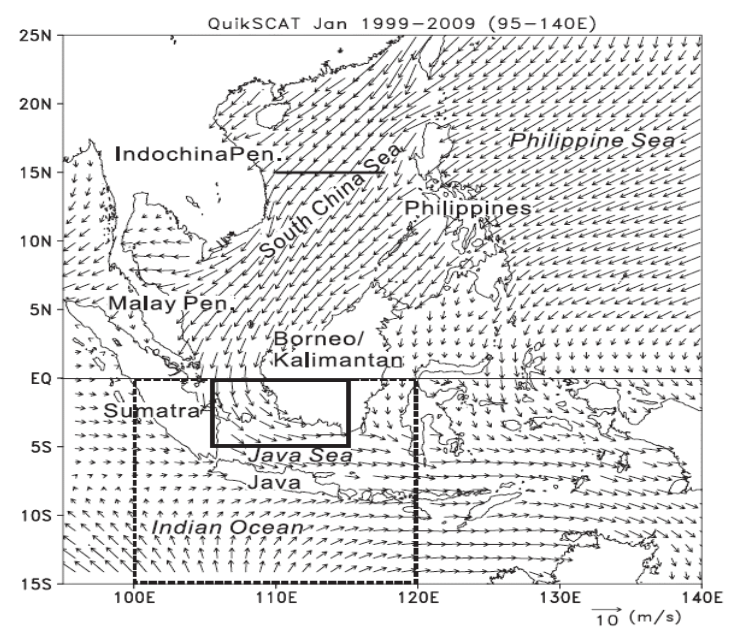

Gambar 1. Penentuan indeks CENS (kotak dengan garis tegas), indeks cold surge (garis lurus), dan wilayah penentuan MJO berdasarkan nilai OLR (kotak dengan garis putus - putus) (Hattori et al., 2011). 
Sementara kejadian cold surge diidentifikasi berdasarkan kecepatan angin meridional lapisan $925 \mathrm{mb}$ di $110^{\circ} \mathrm{BT}-117,5^{\circ} \mathrm{BT}$, $15^{\circ} \mathrm{LU}$ yang mencapai $8 \mathrm{~m} / \mathrm{s}$ atau lebih. Sedangkan MJO diidentifikasi berdasarkan nilai OLR di wilayah $15^{\circ} \mathrm{LS}-\mathrm{Eq}$ dan $100^{\circ} \mathrm{BT}-120^{\circ} \mathrm{BT}$. Dimana saat nilai rata - rata OLR di wilayah ini mencapai kurang dari $210 \mathrm{Wm}^{-2}$ maka MJO aktif di wilayah tersebut. Wilayah identifikasi MJO ini merujuk pada penelitian sebelumnya oleh Murakami (1980) dan Lau \& Chan (1986).

\section{HASIL DAN PEMBAHASAN}

\subsection{Identifikasi CENS}

Pada Gambar 2 disajikan diagram hovmoller rata - rata angin meridional pada bujur $105^{\circ} \mathrm{BT}$ hingga $115^{\circ} \mathrm{BT}$ pada bulan Januari hingga Maret 2013. Dari data ini, CENS diidentifikasi sebagai angin utaraan yang secara intensif melintasi equator berdasarkan nilai kecepatan angin yang mencapai $5 \mathrm{~m} / \mathrm{s}$ atau lebih pada ekuator hingga $5^{\circ}$ LS. Terlihat adanya angin utaraan yang secara intensif melintasi equator pada bulan Januari hingga awal Februari dengan angin terkuat terjadi pada awal Januari mencapai 6 hingga $8 \mathrm{~m} / \mathrm{s}$.

Aliran lintas equator kembali terlihat dengan intensitas yang lebih lemah berkisar antara 4 hingga $6 \mathrm{~m} / \mathrm{s}$ pada akhir dasarian pertama Februari hingga awal Maret. Meskipun intensitasnya lebih lemah, namun angin utaraan pada periode ini mencapai $12^{\circ} \mathrm{LS}$, lebih jauh dibandingkan dengan periode lainnya yang hanya mencapai $3^{\circ}$ LS. Pada dasarian pertama bulan Maret, angin utaraan cukup kuat dengan kecepatan mencapai $8 \mathrm{~m} / \mathrm{s}$ terlihat namun lebih singkat dibandingkan pada bulan Januari 2013. Dibandingkan dengan klimatologisnya, angin utaraan pada periode Januari hingga Maret 2013 lebih kuat, dan dapat mencapai $15^{\circ} \mathrm{LS}$ pada akhir bulan Februari.

Secara umum berdasarkan definisi CENS menurut Hattori (2011), maka pada bulan Januari hingga Maret 2013 terjadi CENS pada tanggal 1 Januari - 2 Februari, 8 - 25 Februari, dan 2 - 8 Maret.

Sementara itu, kejadian cold surge diidentifikasi berdasarkan kecepatan rata - rata angin utaraan pada koordinat $110^{\circ} \mathrm{BT}-117,5^{\circ} \mathrm{BT}$, $15^{\circ} \mathrm{LU}$ yang mencapai $8 \mathrm{~m} / \mathrm{s}$ atau lebih, pada periode yang sama hanya terdapat 5 kejadian yaitu pada tanggal 3 - 6 Januari, 9 - 14 Januari, 16 - 18 Januari, 21 - 23 Februari, dan 3 - 5 Maret. Adapun kejadian MJO terlihat di seluruh area pada tanggal $16-26$ Februari dan $1-11$ Januari. Terdapat satu kejadian dengan nilai OLR rendah di rentang bujur $100^{\circ} \mathrm{BT}-108^{\circ} \mathrm{BT}$ pada tanggal 4 - 7 Februari, yang pada penelitian ini akan diidentifikasi sebagai satu kejadian MJO karena mencakup wilayah penelitian.

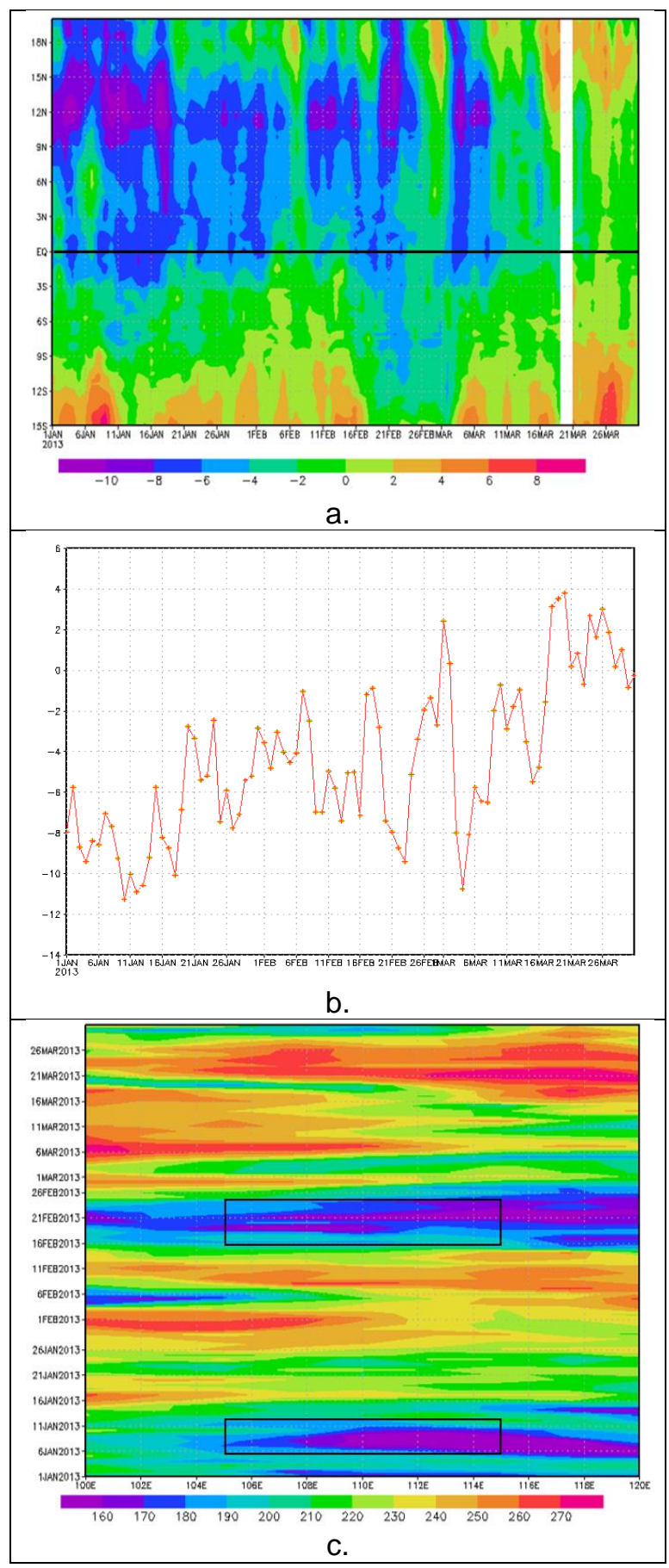

Gambar 2. (a). Hovmoller penampang melintang waktu-lintang rata - rata angin meridional pada bujur $105^{\circ} \mathrm{BT}-115^{\circ} \mathrm{BT}$; (b). Indeks cold surge

(tengah); dan (c). Hovmoller penampang melintang bujur-waktu rata - rata OLR pada lintang $15^{\circ} \mathrm{LS}-\mathrm{Eq}$.

Dengan demikian, berdasarkan hasil identifikasi yang telah dilakukan dari ketiga indeks tersebut, didapatkan kejadian CENS pada bulan Januari hingga Maret 2013 seperti pada Tabel 1 berikut: 
Tabel 1. Tabel Kejadian CENS Periode Januari - Maret 2013.

\begin{tabular}{lcc}
\hline & Ada MJO & Tidak ada \\
& & MJO \\
\hline Ada Cold & 3-5 Jan & 12-14 Jan \\
Surge & 9-11 Jan & 16-18 Jan \\
& 21-23 Feb & \\
\hline Tidak ada & 7-8 Jan & 28 Jan-3 Feb \\
Cold Surge & 18-20 Feb & 6-9 Mar \\
\hline
\end{tabular}

Selanjutnya, analisis dilakukan pada masing - masing kejadian pada rentang waktu 2 hari sebelum hingga 2 hari sesudah kejadian CENS ( $\mathrm{t}=-2$ hingga $\mathrm{t}=+2$ ). Waktu saat kejadian $(\mathrm{t}=0)$ ditentukan berdasarkan nilai indeks CENS tertinggi, sedangkan waktu sebelum kejadian digunakan waktu sebelum indeks CENS mencapai $5 \mathrm{~m} / \mathrm{s}$ dan waktu setelah kejadian digunakan waktu setelah indeks CENS telah bernilai kurang dari $5 \mathrm{~m} / \mathrm{s}$. Adapun pemilihan kejadian didasarkan pada perbedaan waktu saat indeks CENS mencapai maksimum. Kejadian yang dianalisis yaitu saat indeks CENS bernilai maksimum di tengah periode kejadian.

Dengan demikian, pada penelitian ini terdapat empat kejadian yang akan dikaji yaitu CENS bersama - sama dengan cold surge dan MJO tanggal 3 - 5 Januari, CENS bersama sama dengan cold surge tanggal 16 - 18 Januari, CENS bersama - sama dengan MJO tanggal 18 -20 Februari, dan CENS tanpa disertai cold surge maupun MJO tanggal 6 - 9 Maret.

Pada masing - masing kejadian tersebut, digunakan waktu sebelum kejadian yaitu 2 hari sebelum ( $t=-2)$, dan waktu setelah kejadian yaitu 2 hari setelahnya $(\mathrm{t}=+2)$. Digunakan time lag 2 hari karena pendeknya durasi kejadian dan jeda yang berdekatan antara satu periode kejadian dengan lainnya.

Apabila digunakan time lag lebih dari 2 hari, maka waktu sebelum dan sesudah akan bertepatan dengan waktu kejadian lainnya. Pada kejadian CENS bersama - sama dengan MJO, waktu setelah kejadian tidak merepresentasikan kondisi CENS telah berakhir, dimana saat $\mathrm{t}=+2$ indeks CENS kembali menunjukkan nilai $6 \mathrm{~m} / \mathrm{s}$. oleh karena itu, pada periode kejadian ini, digunakan $\mathrm{t}=+1$ sebagai waktu setelah kejadian. Demikian pula pada kejadian CENS disertai cold surge baik pada waktu awal maupun waktu akhir tidak dapat merepresentasikan sebelum dan setelah berakhirnya CENS. Dengan waktu awal digunakan $\mathrm{t}=-1$ karena adanya kejadian MJO pada $\mathrm{t}=-2$ dan sebelumnya. Dan pada periode ini, indeks CENS menguat hingga periode yang cukup lama, sehingga pada periode ini, waktu awal dan waktu akhir hanya merepresentasikan waktu sebelum dan sesudah kesertaan cold surge.
Puncak CENS pada masing - masing periode ini yaitu pada tanggal 4 Januari 2013,16 Januari 2013, 19 Februari 2013, dan 8 Maret 2013.

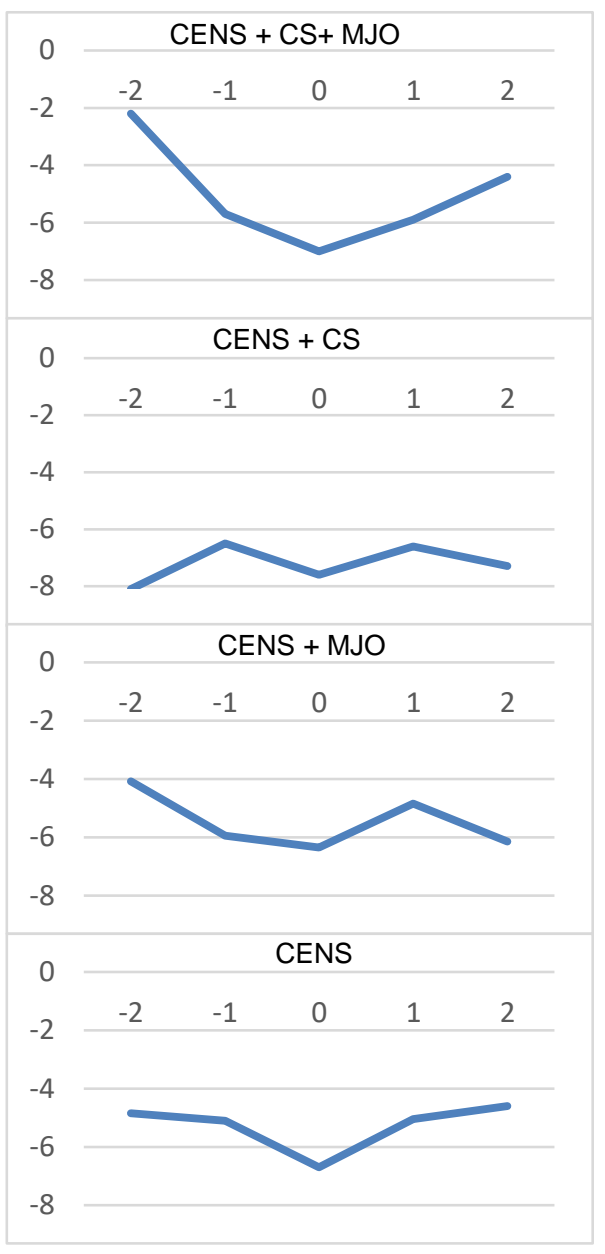

Gambar 3. Time series indeks CENS untuk masing - masing kejadian, sumbu $x$ menunjukan waktu $\mathrm{t}=-2$ hingga $\mathrm{t}=+2$, sumbu y menyatakan indeks CENS dalam satuan $\mathrm{m} / \mathrm{s}$.

Dari Gambar 3 terlihat bahwa saat disertai dengan cold surge, penguatan angin utaraan di sekitar equator berlangsung lebih lama dan dengan kecepatan yang lebih tinggi dibandingkan dengan kejadian tanpa disertai cold surge. Hal ini sesuai dengan hasil penelitian oleh Hattori (2011), kejadian CENS disertai cold surge berlangsung lebih intensif dengan periode yang lebih lama. Apabila dibandingkan berdasarkan Gambar 2.a, maka intensifikasi angin utaraan terjadi paling kuat pada periode CENS disertai MJO, dimana CENS mencapai hingga $12^{\circ} \mathrm{S}$ meskipun dengan kecepatan yang cukup lemah apabila dibandingkan dengan periode kejadian disertai dengan cold surge. Pada periode ENS disertai MJO ini terlihat bahwa CENS berlangsung lebih lama meskipun lemah dibandingkan kejadian lainnya. 


\subsection{Analisis Dinamika Atmosfer}

\subsubsection{Analisis Pola Angin}
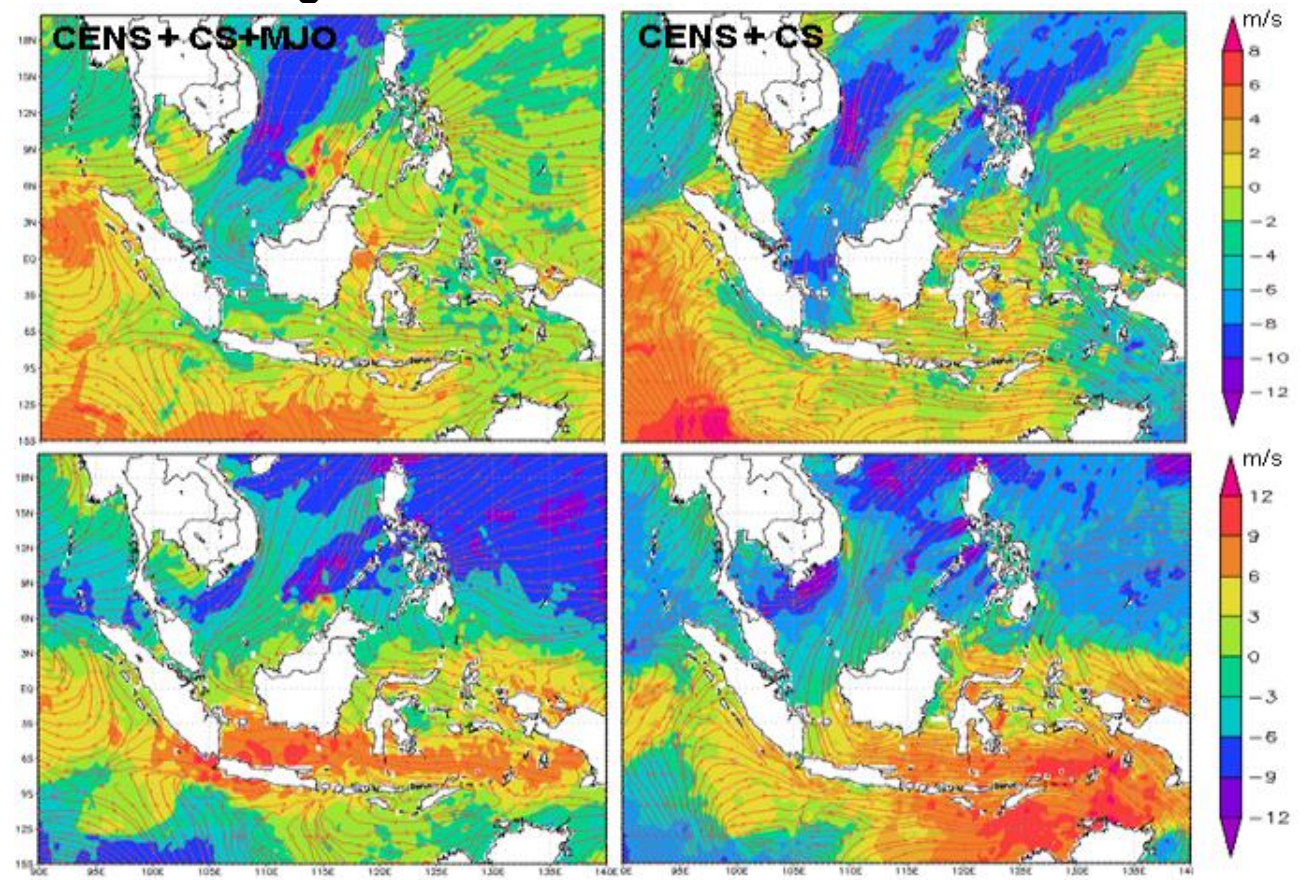

Gambar 4. Komponen angin meridional (atas) dan zonal (bawah) saat $t=0$ untuk kejadian CENS disertai cold surge dan MJO (kiri), dan disertai cold surge (kanan).
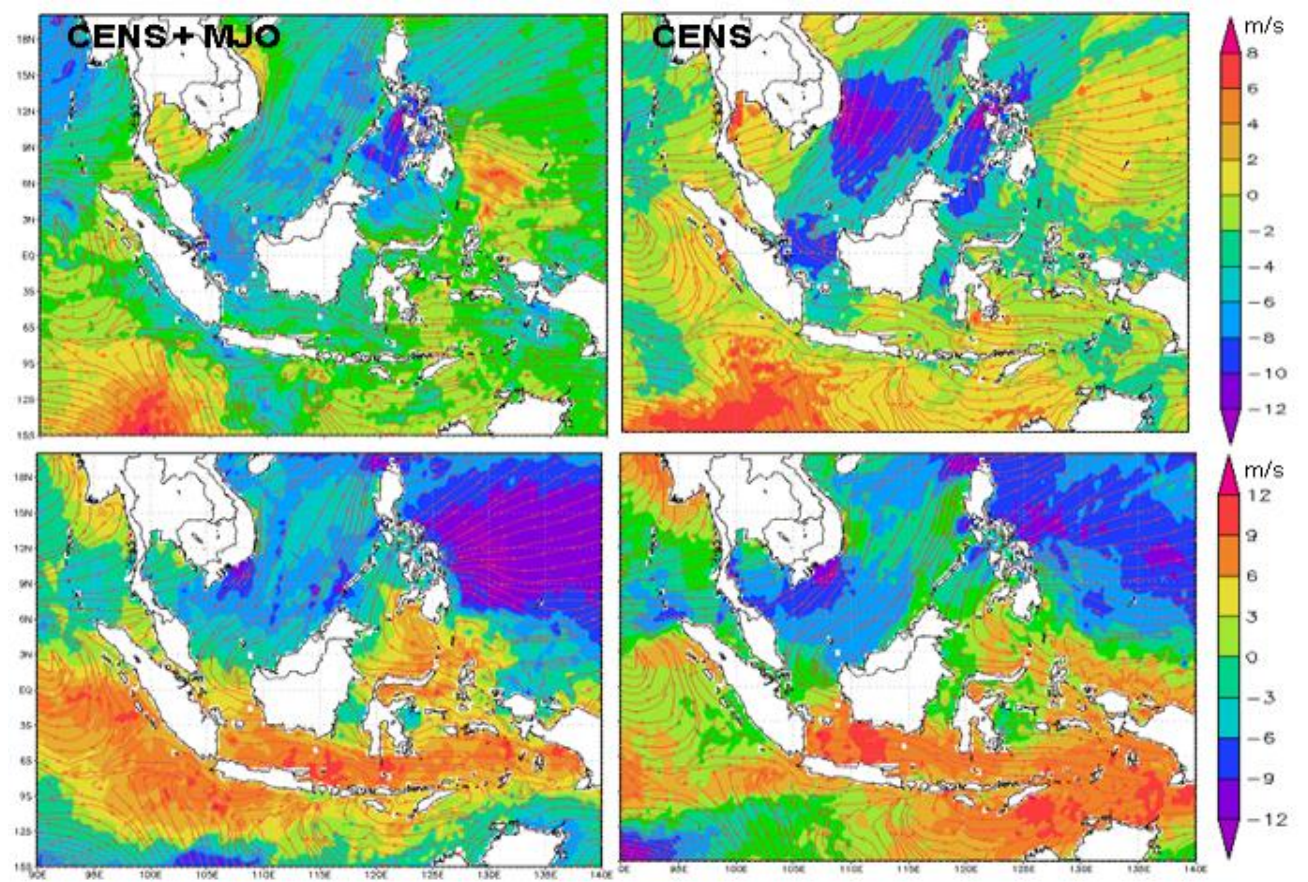

Gambar 5. Komponen angin meridional (atas) dan zonal (bawah) saat $\mathrm{t}=0$ untuk kejadian CENS disertai MJO (kiri), dan tanpa disertai cold surge maupun MJO (kanan)

Sesuai dengan analisis berdasarkan Gambar 3 dan Gambar 2.a, pada Gambar 4 dan 5 terlihat bahwa secara umum, saat CENS terjadi, angin utaraan memasuki wilayah Indonesia hingga di sekitar selatan Bangka Belitung kemudian menjadi angin barat hingga barat laut di wilayah Laut Jawa. Pada saat terdapat cold surge, angin dari Belahan Bumi Utara dengan kecepatan hingga mencapai $12 \mathrm{~m} / \mathrm{s}$ kemudian melemah memasuki wilayah Indonesia dengan kecepatan hingga $8 \mathrm{~m} / \mathrm{s}$. Namun, apabila dibandingkan, intensifikasi ke wilayah selatan equator lebih jauh terlihat pada pola kejadian saat disertai dengan MJO. Terlihat pada saat pola MJO angin utaraan lebih lemah namun terjadi hingga wilayah selatan Jawa. Pada saat pola MJO, terlihat adanya angin 
barat laut dari sebelah barat Sumatera yang memengaruhi pola angin hingga wilayah sekitar Jawa. Pada saat pola MJO tanpa disertai dengan cold surge, pola angin barat laut ini terlihat lebih meluas di wilayah selatan equator. Demikian pula terlihat dari angin zonal, angin baratan lebih intensif terjadi pada saat pola MJO tanpa disertai cold surge. Hal menarik terlihat pada pola CENS tanpa disertai cold surge maupun MJO, dimana angin dari Bumi Belahan Utara melemah saat memasuki wilayah Indonesia, namun kembali menguat hingga mencapai $10 \mathrm{~m} / \mathrm{s}$ di dekat equator.

Apabila dibandingkan dengan waktu sebelum dan setelah berlangsungnya CENS, dapat terlihat bahwa saat kejadian CENS berlangsung, terdapat intensifikasi angin utaraan hingga wilayah selatan equator. Pada saat tidak terdapat CENS, angin utaraan ini secara umum lebih lemah.

\subsubsection{Analisis Temperatur}

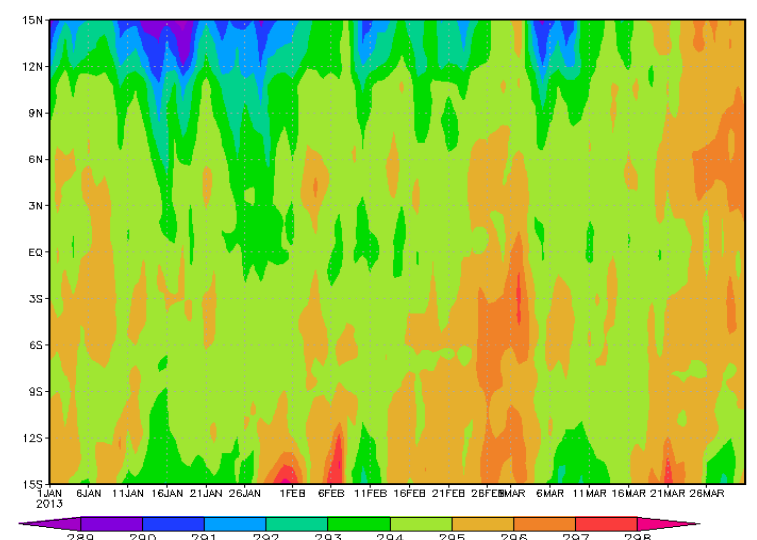

Gambar 6. Hovmoller penampang melintang waktu - lintang rata-rata, temperatur $(\mathrm{K})$ pada $925 \mathrm{mb}$ pada $105^{\circ} \mathrm{BT}-115^{\circ} \mathrm{BT}$.

Analisis temperatur pada lapisan 925mb dilakukan untuk melihat adanya penurunan temperatur udara selama bulan Januari hingga Maret 2013. Penurunan udara di wilayah Indonesia pada saat monsun dingin Asia dapat terjadi salah satunya apabila terdapat penjalaran massa udara dingin dari benua Asia atau yang biasa disebut cold surge. Pada penelitian ini identifikasi cold surge dilakukan berdasarkan penguatan angin meridional di wilayah perairan Laut China Selatan bagian utara, berdasarkan identifikasi ini, kejadian cold surge dapat teridentifikasi meskipun tanpa disertai adanya penjalaran massa udara dingin ke wilayah Indonesia.

Dari Gambar 6, terlihat bahwa selama periode penelitian, penjalaran suhu udara dingin yang menuju benua maritim terjadi dua kali yakni pada pertengahan Januari 2013 dan pada akhir
Januari. Pada periode pertengahan Januari, suhu udara dingin ini tidak mencapai ekuator sedangkan pada periode akhir Januari, telihat suhu udara dingin ini melintasi ekuator hingga mencapai $2^{\circ}$ LS. Adanya suhu udara dingin yang memasuki Indonesia ini dapat menjadi indikasi akan adanya adveksi dingin di wilayah yang dilaluinya, dimana adveksi dingin ini dapat memicu pembentukan cuaca signifikan di wilayah tersebut (Swarinoto, 1996).

\subsubsection{Analisis Divergensi}

Pada Gambar 7 dan 8, pola konvergensi dan divergensi didapatkan dari nilai divergensi dimana pada nilai divergensi negatif (warna biru hingga ungu) merupakan konvergensi, dan sebaliknya saat positif (warna kuning hingga merah) merupakan divergensi. Dari gambar tersebut, secara umum pada wilayah Laut China Selatan wilayah Indonesia di sekitar equator, kecepatan angin cenderung tetap. Terlihat adanya perbedaan signifikan di wilayah sekitar equator pada pola cold surge dan MJO dengan hanya cold surge, dimana pada pola cold surge dan MJO nilai divergensi bernilai negatif hingga $-5 \mathrm{~s}^{-1}$, sebaliknya pada pola cold surge nilai divergensi bernilai positif hingga $20 \mathrm{~s}^{-1}$. Hal ini terkait dengan peningkatan kecepatan angin secara signifikan pada pola cold surge saat memasuki wilayah Indonesia.

Sementara pada pola cold surge dan MJO, konvergensi terjadi selain karena adanya pengurangan kecepatan yang tidak signifikan, juga adanya pertemuan angin baratan dari sebelah barat Sumatera. Hal seperti ini juga terlihat untuk pola MJO, dimana konvergensi dengan angin baratan terjadi di sebelah selatan Bangka hingga Laut Jawa. Sedangkan pada pola CENS, adanya konvergensi di wilayah yang sama diakibatkan adanya tekanan rendah di sebelah barat daya Sumatera pada saat kejadian.

Dari analisis ini didapatkan bahwa pada saat berlangsungnya CENS, konvergensi di wilayah sekitar equator cenderung terjadi akibat dari gangguan di sebelah barat maupun barat daya Sumatera. Gangguan dapat berupa aktivitas MJO maupun wilayah tekanan rendah. Sementara pada saat kejadian cold surge, dengan peningkatan kecepatan angin yang menuju ke wilayah Indonesia menyebabkan terjadinya divergensi hingga selatan equator.

Hasil serupa ditunjukkan pada penelitian Chang (2005) dimana secara umum pada saat kejadian cold surge terjadi divergensi hingga mencapai equator, namun pada saat mencapai wilayah Jawa, terdapat kemungkinan terjadinya konvergensi pada skala lokal yang dapat menyebabkan cuaca buruk di wilayah ini (Wu et al., 2013). 

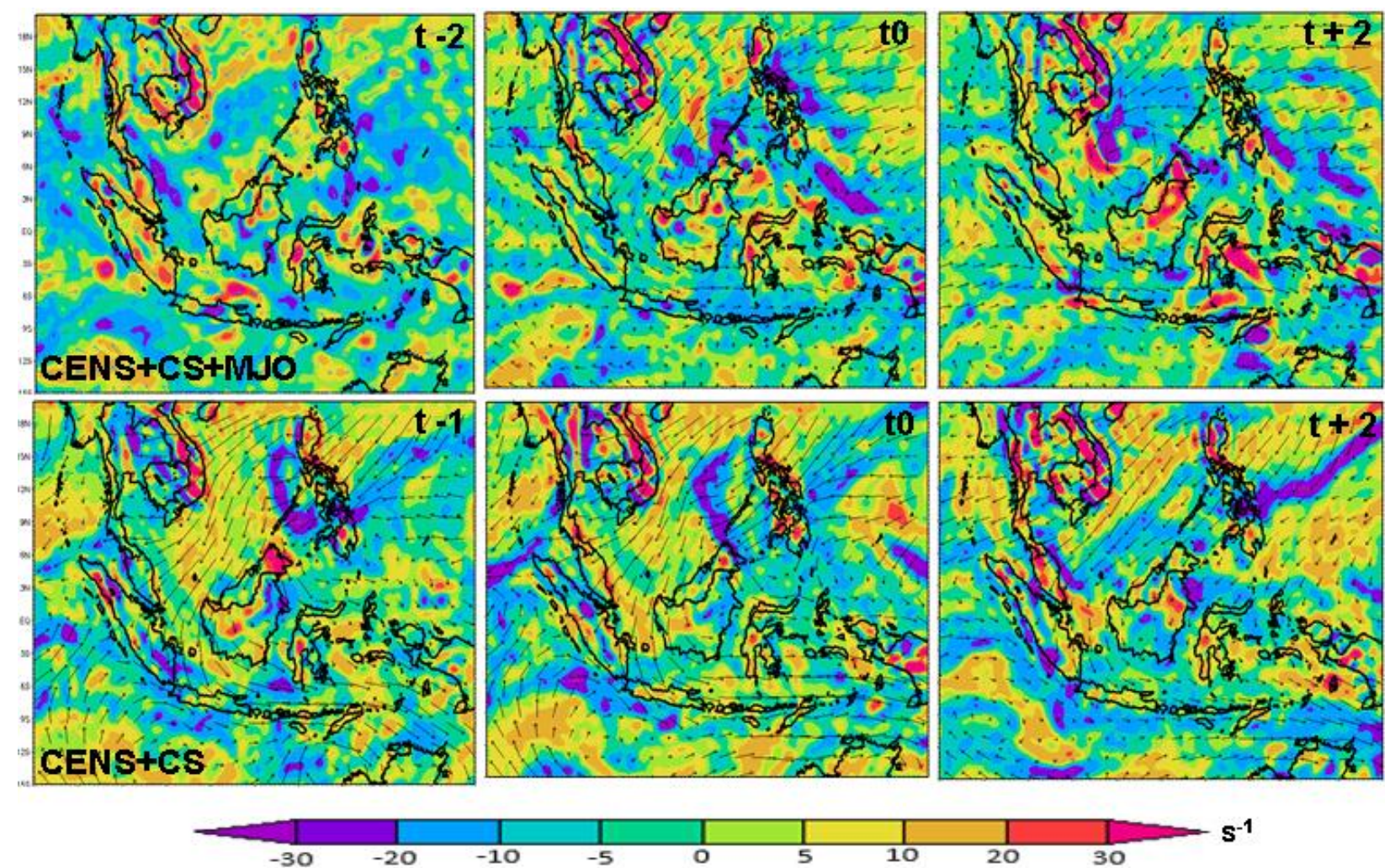

Gambar 7. Pola divergensi pada saat kejadian CENS disertai CS dan MJO, dan disertai CS (atas ke bawah); pada waktu sebelum kejadian ( $\mathrm{t}=-2)$, saat kejadian $(\mathrm{t}=0)$, dan setelah kejadian $(\mathrm{t}=+2)$ (kiri ke kanan).
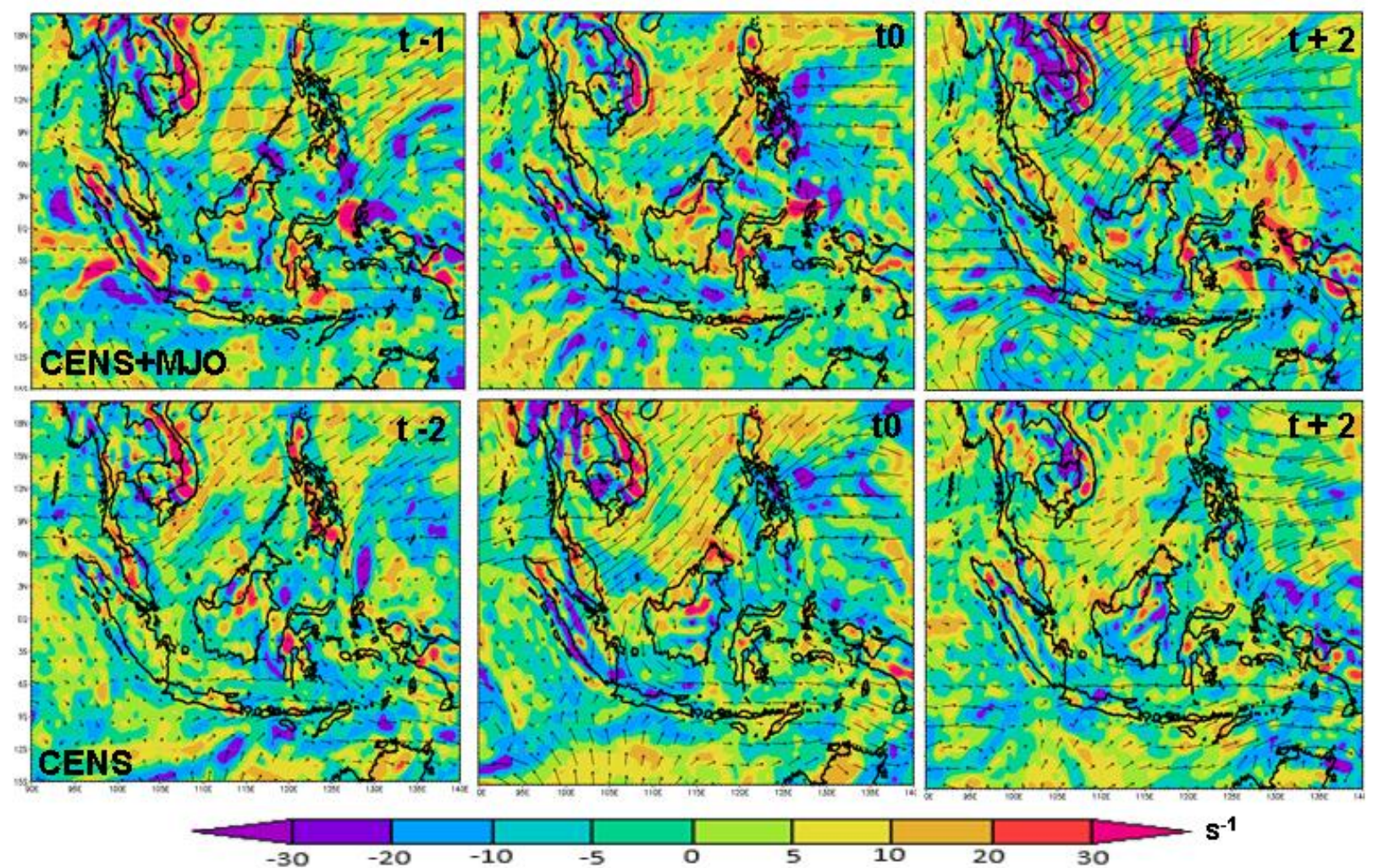

Gambar 8. Pola divergensi pada saat kejadian CENS disertai MJO, dan hanya CENS (atas ke bawah); pada waktu sebelum kejadian $(\mathrm{t}=-2)$, saat kejadian $(\mathrm{t}=0)$, dan setelah kejadian $(\mathrm{t}=+2)$ (kiri ke kanan). 


\subsection{Analisis Vertical Velocity}
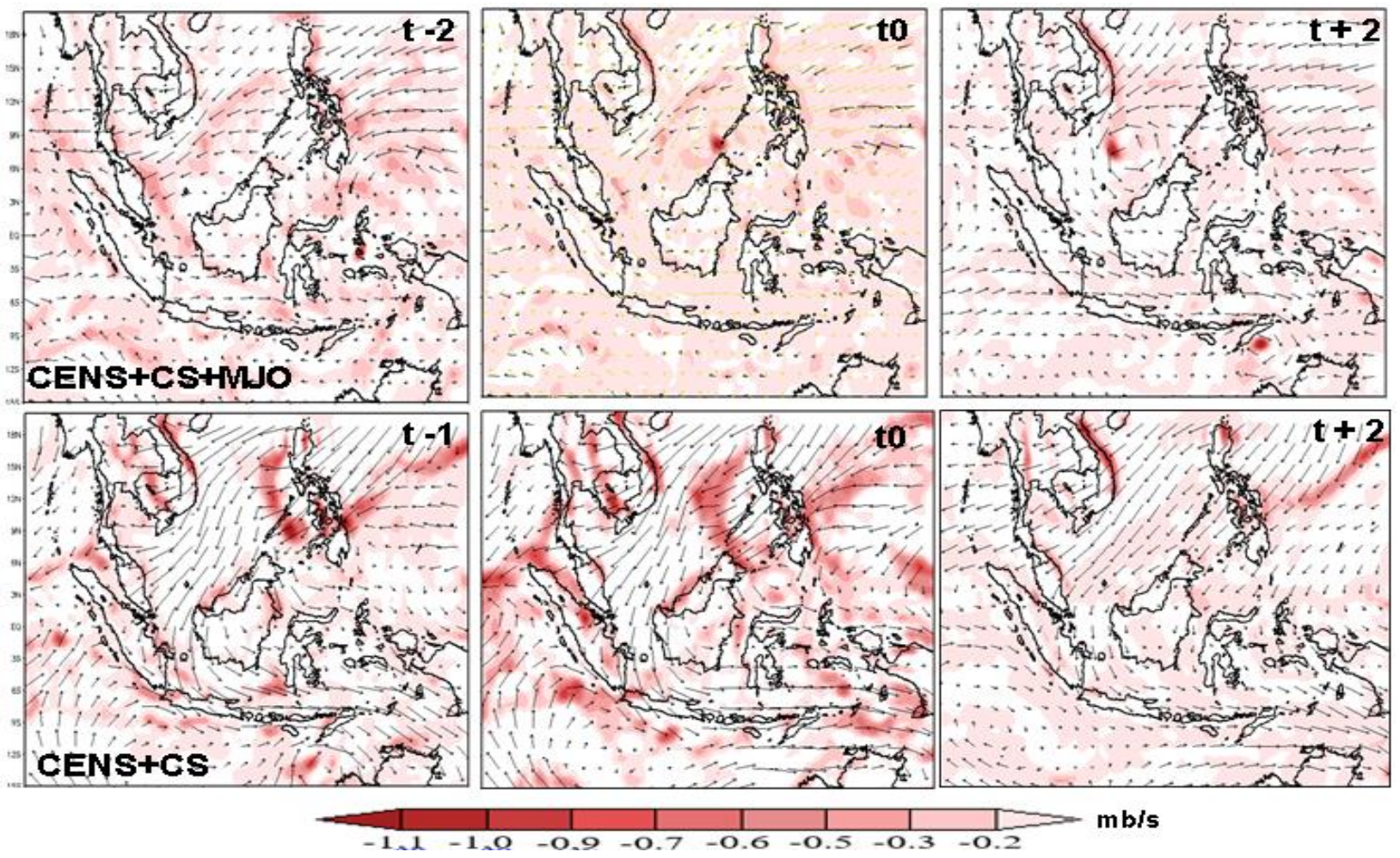

Gambar 9. Vertical velocity pada saat kejadian CENS disertai CS dan MJO, dan disertai CS (atas ke bawah); pada waktu sebelum kejadian ( $\mathrm{t}=-2)$, saat kejadian $(\mathrm{t}=0)$, dan setelah kejadian $(\mathrm{t}=+2)$ (kiri ke kanan).
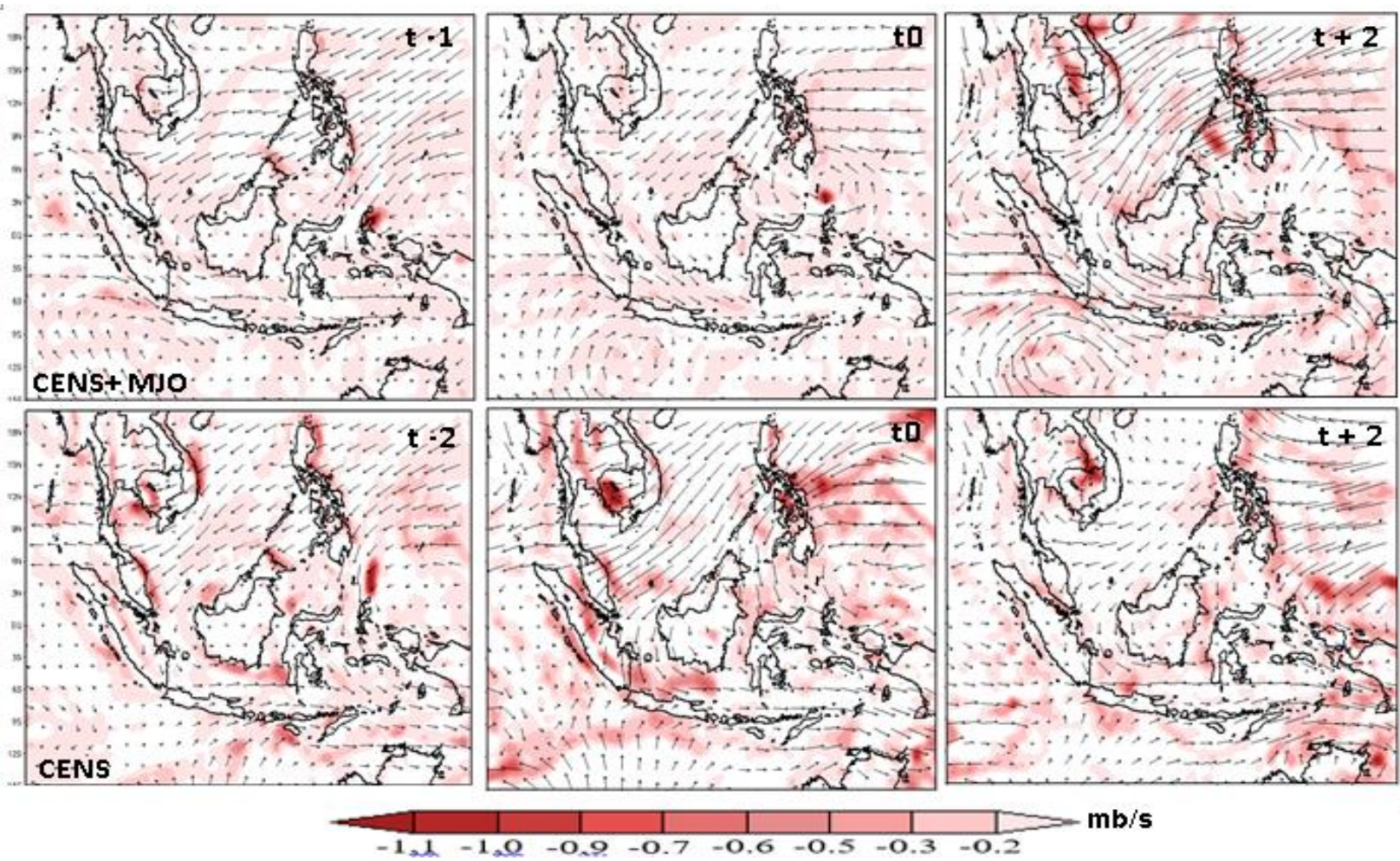

Gambar 10. Vertical velocity pada saat kejadian CENS disertai MJO, dan tanpa disertai CS maupun MJO (atas ke bawah); pada waktu sebelum kejadian $(\mathrm{t}=-2)$, saat kejadian $(\mathrm{t}=0)$, dan setelah kejadian $(\mathrm{t}=+2)$ (kiri ke kanan). 
Analisis vertical velocity menunjukkan potensi pergerakan vertikal massa udara dimana nilai negatif pada vertical velocity menunjukkan adanya pergerakan naik, semakin kecil nilai vertical velocity, maka pergerakan vertikal massa udara semakin kuat dan stabilitas atmosfer semakin labil. Dari Gambar 9 dan 10 terlihat bahwa vertical velocity terjadi lebih luas terutama di wilayah perairan pada saat terjadi CENS. Gerakan vertikal ke atas terjadi dalam luasan paling luas terjadi saat CENS disertai cold surge dan $\mathrm{MJO}$, terlihat pada $\mathrm{t}=-2$ omega terjadi lebih kuat namun tidak nampak meluas, sementara pada $\mathrm{t}=+2$ gerak vertikal di wilayah Indonesia umumnya berkurang disebabkan adanya gangguan di Laut China Selatan. Sementara pada saat kejadian CENS disertai cold surge kenaikan massa udara pada umumnya terjadi hanya di daratan terutama di wilayah peisir. Terlihat adanya arah angin menyebar (divergensi) mulai dari Laut China Selatan hingga wilayah perairan Indonesia. Adanya kenaikan vertikal di wilayah pesisir dapat disebabkan adanya konvergensi akibat interaksi dengan angin lokal. Apabila dibandingkan dengan waktu sebelum dan setelah adanya cold surge, maka terbukti bahwa CENS memperkuat vertical motion yang terjadi. Pada pola CENS disertai MJO, terdapat kenaikan vertikal di wilayah Laut China Selatan baik saat sebelum, saat kejadian, maupun sesudah adanya CENS. Selain itu, kenaikan vertikal yang lebih kuat juga terlihat di Laut Jawa.

Pola yang serupa dengan CENS disertai cold surge terlihat pada pola hanya CENS, dimana pada saat kejadian CENS $(\mathrm{t}=0)$ terdapat kenaikan vertikal yang lebih kuat dibandingkan saat sebelum maupun sesudah kejadian CENS. Kenaikan vertikal yang kuat pada umumnya terjadi di wilayah Laut China Selatan bagian selatan, pesisir timur Sumatera, dan Laut Jawa. Kenaikan vertikal di Laut Jawa terjadi akibat adanya belokan angin serta konvergensi.

\subsection{Analisis Transpor Kelembapan}

Analisis transpor kelembapan pada lapisan 1000 hingga $850 \mathrm{mb}$ dapat menggambarkan secara jelas mengenai distribusi massa udara yang memasuki wilayah Indonesia. Dari Gambar 11 dan 12 juga didapatkan bahwa pada $t=0$ atau pada saat berlangsung CENS terdapat aliran massa udara dari Belahan Bumi Utara memasuki wilayah Indonesia hingga melintasi equator. Apabila dibandingkan dengan waktu sebelum dan setelahnya, maka dapat disimpulkan dalam hal ini CENS berperan sebagai pembawa massa udara dari Benua Asia ke wilayah Indonesia. Pada kejadian CENS disertai cold surge dan MJO saat $\mathrm{t}=+2$ terlihat bahwa gangguan yang terjadi di Laut China Selatan dapat menghalangi masuknya massa udara ke wilayah Indonesia. Selain itu, dari transpor kelembapan juga dapat terlihat bahwa pada saat pola MJO, terdapat adanya transpor kelembapan dari Samudera Hindia terutama di sebelah barat Sumatera bagian selatan. Hal ini sangat jelas telihat pada pola MJO bahwa meskipun transpor kelembapan dari utara tidak intensif, namun wilayah sekitar Jawa mendapatkan massa udara dari sebelah barat Sumatera.
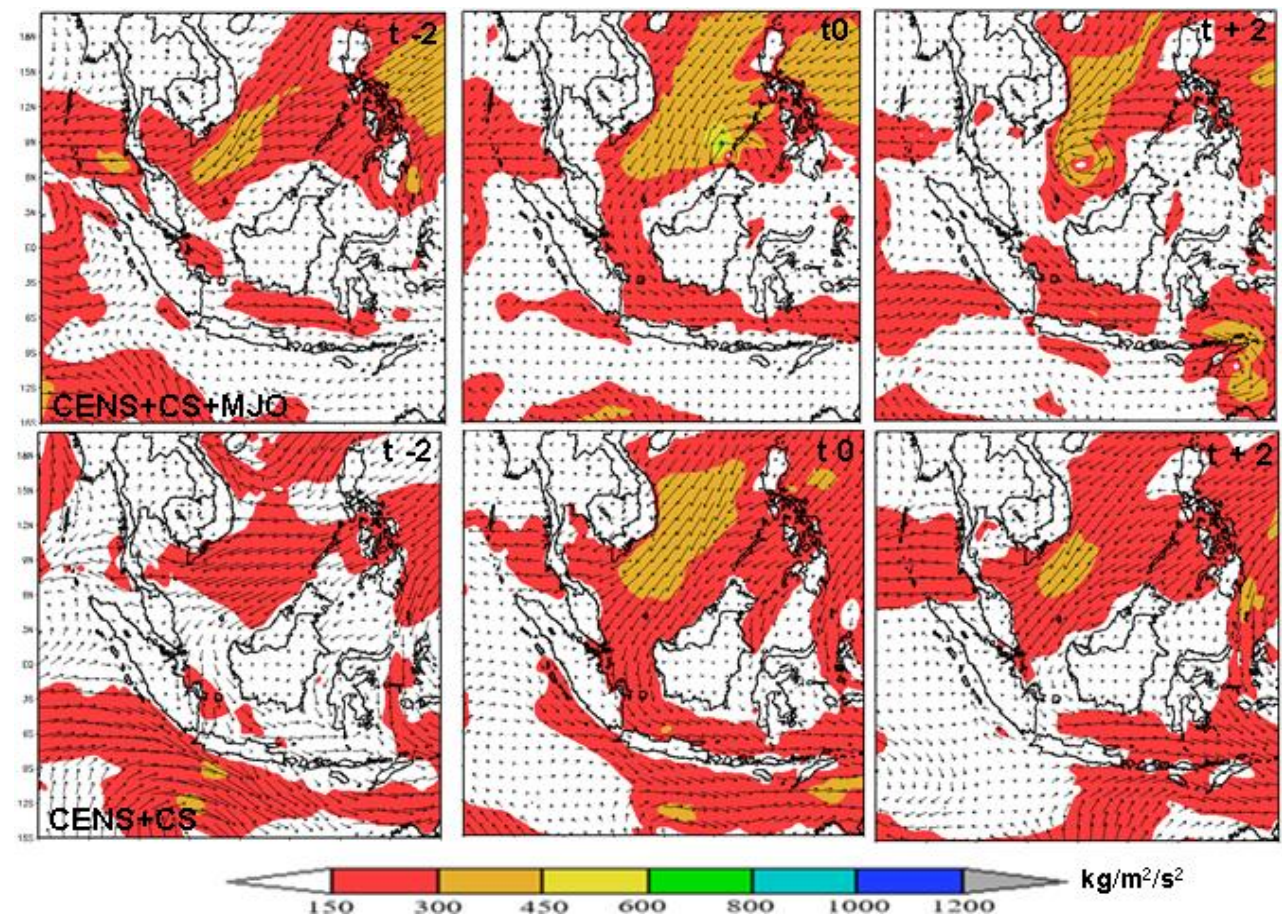

Gambar 11. Transpor kelembapan pada saat kejadian CENS disertai CS dan MJO, dan disertai CS (atas ke bawah); pada waktu sebelum kejadian $(\mathrm{t}=-2)$, saat kejadian $(\mathrm{t}=0)$, dan setelah kejadian $(\mathrm{t}=+2)$ (kiri ke kanan). 


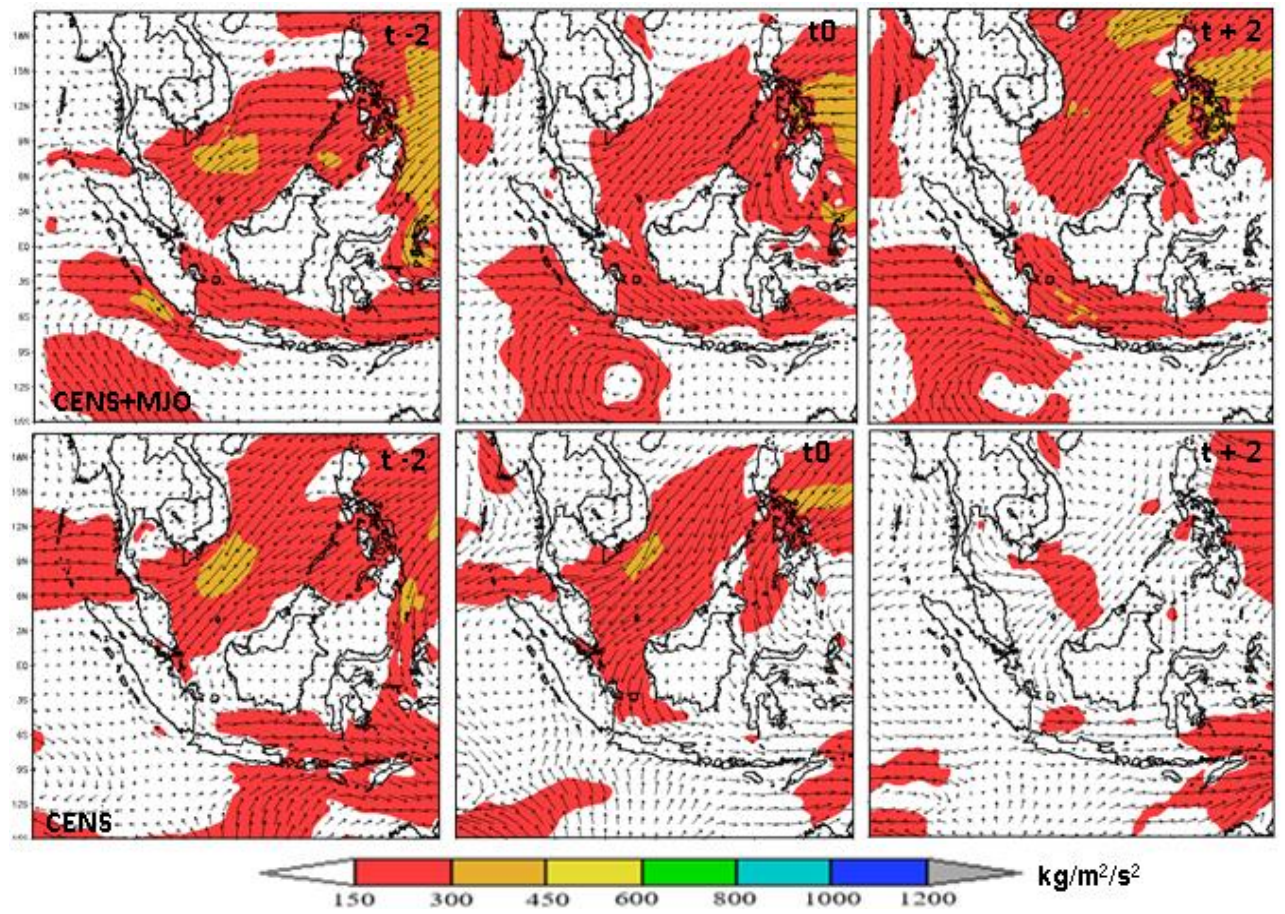

Gambar 12. Transpor kelembapan pada saat kejadian CENS disertai MJO, dan hanya CENS (atas ke bawah); pada waktu sebelum kejadian $(\mathrm{t}=-2)$, saat kejadian $(\mathrm{t}=0)$, dan setelah kejadian $(\mathrm{t}=+2)$ (kiri ke kanan).

\section{KESIMPULAN}

1. Penggunaan indeks CENS sangat efektif dalam menggambarkan intensifikasi angin utaraan di equator, namun tidak selalu dapat merepresentasikan masuknya massa udara dari Benua Asia, misalnya pada saat terdapat gangguan di Laut China Selatan.

2. Terdapat perbedaan yang terlihat cukup jelas pada pola angin zonal dan meridional, divergensi, serta omega di wilayah Indonesia bagian barat, menunjukkan bahwa CENS merupakan faktor penting yang berperan pada dinamika atmosfer di wilayah Indonesia bagian barat.

\section{DAFTAR PUSTAKA}

Aldrian, E., Utama, G.S.A. (2007). Identifikasi dan Karakteristik Seruakan Dingin (Cold Surge) Tahun 1995-2003. Jurnal Sains Dirgantara, 4(2), 107-127.

Chang, C.P., Harr, P.A., Chen, H.J. (2005). Synoptic Disturbances over the Equatorial South China Sea and Western Maritime Continent During Boreal Winter. Monthly Weather Review, 133(3), 489 - 503. doi: 10.1175/MWR-2868.1

Chang, C.P., Lu, M.M., Lim, H. (2016). Monsoon Convection in the Maritime Continent: Interaction of Large-Scale Motion and Complex Terrain. Meteorological Monographs, Chapter 6. doi: 10.1175/AMSMONOGRAPHS-D-150011.1
Hattori, M., Mori, S., Matsumoto, J. (2011). The Cross-Equatorial Northerly Surge over the Maritime Continent and Its Relationship to Precipitation Patterns. Journal of the Meteorological Society of Japan, 89A, 2747. doi: 10.2151/jmsj.2011-A02

Lau, K.M., Chan, P.H. (1986). Aspects of the $40-$ 50 Day Oscillation During the Northern Winter as Inferred from Outgoing Longwave Radiation. Monthly Weather Review, 114(7), 1354-1367. doi: 10.1175/15200493(1986)114<1354:AOTDOD>2.0.CO;2

Mori, S., Wu, P., Yamanaka, M.D., Hattori, M., Hamada, J.I., Arbain, A.A., Lestari, S., Sulistyowati, R., Syamsudin, F. (2016). Lightning Climatology over Jakarta, Indonesia, Based on Long-Term Surface Operational, Satellite, and Campaign Observations. Geophysical Research Abstracts, 18, EGU2016-5307-2, EGU General Assembly 2016.

Mori, S., Hamada, J.I., Hattori, M., Wu, P.M., Katsumata, M., Endo, N., Ichiyanagi, K., Hashiguchi, H., Arbain, A.A., Sulistyowati, R., Lestari, S., Syamsudin, F., Manik, T., Yamanaka, M.D. (2018). Meridional March of Diurnal Rainfall over Jakarta, Indonesia, Observed with a C-band Doppler Radar: An Overview of the HARIMAU2010 Campaign. Progress in Earth and Planetary Science, 5, 47. doi:10.1186/s40645-018-0202-9

Moron, V., Robertson, A.W., Qian, J.H. (2010). Local versus Large-Scale Characteristics of Monsoon Onset and Post-Onset Rainfall 
over Indonesia. Climate Dynamics, 34, 281-299. doi: 10.1007/s00382-009-0547-2

Murakami, T. (1980). Temporal Variations of Satellite Observed Outgoing Longwave Radiation over the Winter Monsoon Region. Part I: Long Period (15-30 Day) Oscillations. Monthly Weather Review, 108(4), 408-426. doi: 10.1175/15200493(1980)108<0408:TVOSOO>2.0.CO;2

Swarinoto, Y.S. (1996). Studi tentang Aliran Lintas Ekuator pada Paras $850 \mathrm{mb}$ di Daerah Sekitar Laut Jawa. Skripsi. Universitas Indonesia: Depok.
Wu, P., Arbain, A.A., Mori, S., Hamada, J.I., Hattori, M., Syamsudin, F., Yamanaka, M.D. (2013). The Effects of an Active Phase of the Madden-Jullian Oscillation on the Extreme Precipitation Event over Western Java Island in January 2013. SOLA, 9, 7983. doi: 10.2151/sola.2013-018

Yulihastin, E. (2015). Pengaruh Cross-Equatorial Northerly Surge (CENS) terhadap Presipitasi pada Kasus Banjir Jakarta 2013. Tesis, Institut Teknologi Bandung: Bandung. 